Original Article

\title{
Eugenol and its liposome-based nano carrier reduce anxiety by inhibiting glyoxylase- 1 expression in mice
}

\author{
Eugenol e seu nanocarreador à base de lipossoma reduzem a ansiedade ao inibir a \\ expressão de glioxalase 1 em camundongos
}

\author{
F. J. Siyala ${ }^{\mathrm{a}, \mathrm{b}}$ (D), R. A. Siddiqui ${ }^{*}$, Z. Memon ${ }^{\mathrm{d}}$, Z. Aslame, U. Nisar ${ }^{\mathrm{a}}$, R. Imad ${ }^{\mathrm{c}}$ and M. R. Shahe \\ aZiauddin University, Faculty of Pharmacy, Department of Pharmacology, Karachi, Pakistan \\ 'Shaheed Mohtarma Benazir Bhutto Medical University, Institute of Pharmacy, Larkana, Pakistan \\ 'Ziauddin University, Department of Research, Karachi, Pakistan \\ ¿Ziauddin University, Ziauddin Medical College, Department of Pharmacology, Karachi, Pakistan \\ eUniversity of Karachi, International Center for Chemical and Biological Sciences, HEJ Research Institute of Chemistry, Karachi, Pakistan
}

\begin{abstract}
The most common form of psycho-social dysfunction is anxiety with depression being related closely without any age bar. They are present with combined state of sadness, confusion, stress, fear etc. Glyoxalase system contains enzyme named glyoxalase 1 (GLO1).It is a metabolic pathway which detoxifies alpha-oxo-aldehydes, particularly methylglyoxal (MG). Methylglyoxal is mainly made by the breakdown of the glycolytic intermediates, glyceraldehyde-3-phosphates and dihydroxyacetone phosphate. Glyoxylase-1 expression is also related with anxiety behavior. A casual role or GLO-1 in anxiety behavior by using viral vectors for over expression in the anterior cingulate cortex was found and it was found that local GLO-1 over expression increased anxiety behavior. The present study deals with the molecular mechanism of protective activity of eugenol against anxiolytic disorder. A pre-clinical animal study was performed on $42 \mathrm{BALB} / \mathrm{c}$ mice. Animals were given stress through conventional restrain model. The mRNA expression of GLO- 1 was analyzed by real time RT-PCR. Moreover, the GLO- 1 protein expression was also examined by immunohistochemistry in whole brain and mean density was calculated. The mRNA and protein expressions were found to be increased in animals given anxiety as compared to the normal control. Whereas, the expressions were decreased in the animals treated with eugenol and its liposome-based nanocarriers in a dose dependent manner. However, the results were better in animals treated with nanocarriers as compared to the compound alone. It is concluded that the eugenol and its liposome-based nanocarriers exert anxiolytic activity by down-regulating GLO-1 protein expression in mice.
\end{abstract}

Keywords: anxiety, eugenol, liposomes, glyoxalase-1.

\begin{abstract}
Resumo
A forma mais comum de disfunção psicossocial é a ansiedade intimamente relacionada com a depressão, sem qualquer barreira de idade. Elas estão presentes em um estado combinado de tristeza, confusão, estresse, medo etc. O sistema de glioxalase contém uma enzima chamada glioxalase 1 (GLO1). É uma via metabólica que desintoxica alfa-oxo-aldeídos, particularmente metilglioxal (MG). O metilglioxal é produzido principalmente pela quebra dos intermediários glicolíticos, gliceraldeído-3-fosfatos e fosfato de diidroxiacetona. A expressão da glioxalase 1 também está relacionada ao comportamento de ansiedade. Um papel casual ou GLO1 no comportamento de ansiedade usando vetores virais para superexpressão no córtex cingulado anterior foi encontrado e descobriu-se que a superexpressão local de GLO1 aumentava o comportamento de ansiedade. O presente estudo trata do mecanismo molecular da atividade protetora do eugenol contra o transtorno ansiolítico. Um estudo pré-clínico em animais foi realizado em 42 camundongos BALB / c. Os animais foram submetidos ao estresse por meio do modelo de contenção convencional. A expressão de mRNA de GLO1 foi analisada por RT-PCR em tempo real. Além disso, a expressão da proteína GLO1 também foi examinada por imuno-histoquímica em todo o cérebro e a densidade média foi calculada. Verificou-se que as expressões de mRNA e proteínas estavam aumentadas em animais que receberam ansiedade em comparação com o controle normal. Considerando que as expressões foram diminuídas nos animais tratados com eugenol e seus nanocarreadores baseados em lipossomas de forma dependente da dose. No entanto, os resultados foram melhores em animais tratados com nanocarreadores em comparação com o composto sozinho. Conclui-se que o eugenol e seus nanocarreadores baseados em lipossomas exercem atividade ansiolítica por regulação negativa da expressão da proteína GLO1 em camundongos.
\end{abstract}

Palavras-chave: ansiedade, eugenol, lipossomas, glioxalase 1.

*e-mail: rehan.siddiqui@zu.edu.pk

Received: April 18, 2021 - Accepted: June 4, 2021

This is an Open Access article distributed under the terms of the Creative Commons Attribution License, which permits unrestricted use, distribution, and reproduction in any medium, provided the original work is properly cited. 


\section{Introduction}

The most common form of psycho-social dysfunction is anxiety (Andrews et al., 2000) with depression being related closely without any age bar. The psycho-social dysfunctions are presented with combined state of sadness, confusion, stress, despair, loneliness, irritability and fear (Andrews et al., 2000). It might lead to a symptom like slow walk i.e. a more complicated psychomotor disorder. Their treatment has become a challenge and only about 5 to 15 percent of peoples recover completely or partially after receiving psychotherapy or drugs and about 20 to 30 percent did not show any response (Coulehan et al., 1997). It is the need of time to search new alternatives in managing anxiety because of their spread and constant progress (Irie et al., 2005). Stress effects on behavior, especially on emotions and cognition (Selvan et al.,2016). It also induce analgesic effects in rodents and humans by affecting sensory perception. Motor performance in rodents and humans are adversely affected by stress (Metz et al., 2005). Anxiety also affect performance and motor activity (Lepicard et al., 2000). Anxiety and stress both modulate motor activity in the open field test (Treit and Fundytus, 1988). Mice strains which develop anxiety has greater impairment in a skill motor task in comparison with less emotional mice (Lepicard et al., 2000). About two-third of depressed and anxious patients are given currently available therapeutics or treatments but their improvement magnitude is not up to the mark. They also produce many side effects (Baldessarini, 2006). A concept of mixed anxiety and depressed disorder was introduced in 1992 by the International Classification of Diseases (Barkow et al., 2004). One of the studies reported to have anxiety and depression occurrence together. Depression can also predispose anxiety or vice versa. Many metabolic and psychiatric disorders are caused due to anxiety. It is also involved in addiction from maintenance and development to relapse of disorder depression and schizophrenia (Brady and Sinha, 2005). It can be said that it is a non-specific reaction of the body towards demand obligatory on it by the way of allostasis, the body responds towards anxiety (McEwen, 2000). The autonomic nervous system and HPA axis (Hypothalamus-pituitary-adrenal axis) are the two main effectors system and the basic function of them to maintain homeostasis. The usage of natural plants as alternative medicine has been on the rise from lasts decade in order to treat many pathological situations because of safety, cost effectiveness, availability and easy to use or administration. It has also got attention for being used in the treatment of degenerative, neurological and psychiatric disorders due to less side effects (Singh et al., 2017). A novel pharmacotherapy is in search especially from medicinal plants and therapeutic effects has been assessed in past in variety of different animal models (Zhang, 2004). Eugenol is a 4-allyl-2-methoxyphenol.It is the main constituent of clove oil and tulsi which are derived from variety of sources of plants such as Myristica fragrans, Osimum sanctumLinn and Eugenia caryophyllus.In past eugenol has been used in dental care for relieving pain arises from different sources like dentinal hypersensitivity and pulpitis. It is used as flavoring agent in sweets, beverages, frozen dairy products and baked food. In traditional medicine it is used in chronic diarrhea, cholic, flatulence and other GIT disorders. It is considered as safe by FDA (food drug administration) (Prakash and Gupta, 2005). Medicinal herbs are considered as the main cornerstone regarding practice of traditional medicines worldwide with majority of the countries are relying on them for health care (Amos et al., 2001). Eugenol is a clear to pale yellow oily liquid which is soluble in the organic solvent and slightly soluble in water. It also possess antiseptic properties and also used in perfumes (Sharma et al., 2012). It is also effective in reversing the short and long term memory (Halder et al., 2011).

Nanotechnology and its advancement has revolutionized 20th century's and it deals with study of very small particles. It causes breakdown of large particles into very small particles. It also deals with materials having size ranging from 0.1 to $100 \mathrm{~nm}$; its working relies on nanometer scale length from 1 to $100 \mathrm{~nm}$ and therefore it can be used in many applications for the creation of nano devices and nanoparticles. Nanomedicine can improve drug bioavailability. Molecular targeting is also done by nano robots which are engineered devices. The main objective of this study was to assess the effects of eugenol and its liposome-based nano carrier onglyoxylase- 1 in anxiety in vivo.

\section{Material and Methods}

\subsection{Preparation of liposome-based nanocarriers loaded with eugenol (Eu-Lipo)}

Liposome-based nanocarriers loaded with eugenol (Eu-Lipo) were synthesized according to our previous protocol (Siyal et al., 2020).

\subsection{Animal studies and treatment regime}

Forty Two (42) adult male BALB/c mice weighing from 25 to $30 \mathrm{gm}$ were purchased from the animal house of Liaquat National Hospital, Karachi and all female mice were excluded due to hormonal level which might cause data variability from estrous cycles. The mice were kept and maintained in the animal house facility of Faculty of Pharmacy, Ziauddin University. All animal experimentations were performed by following international guidelines (Institute of Laboratory Animal Resources, US, 1989) and institutional protocols approved by Animal Ethics Committee of Ziauddin University (Approval Protocol No. 2019-004). Animals were given free access to water and rodent chow in their conventional cages kept at $22-23^{\circ} \mathrm{C}$ with 12-h light-dark cycle. Prior to the start of experiment, animals were acclimatized with the experimenter and the environment for few days and were divided into following groups i.e. Group I: animals were given normal Saline, per oral. Group II: animals were given chronic restraint stress and normal saline, per oral. Group III: animals were given chronic restraint stress and eugenol, $50 \mathrm{mg} / \mathrm{kg}$, per oral. Group IV: animals were given chronic restraint stress and eugenol, $100 \mathrm{mg} / \mathrm{kg}$, per oral. Group V: animals were given chronic restraint stress and Eu-Lipo, $15 \mathrm{mg} / \mathrm{kg}$, per 
oral. Group VI: animals were given chronic restraint stress and Eu-Lipo, $30 \mathrm{mg} / \mathrm{kg}$, per oral. Group VII: animals were given chronic restraint stress and diazepam, $01 \mathrm{mg} / \mathrm{kg}$, per oral. Animals were treated with the test compounds for five days. At the end of the experiment all animals were sacrificed humanly by cervical dislocation and whole brain was dissected out for further studies (Siyal et al., 2020).

\subsection{Conventional restrain model}

In this method each mouse was exposed to restraint and was placed in a conical tube (ventilated) $50-\mathrm{mL}$. They were restrained for five consecutive nights through period of each day i.e. restraint stress, from 17: 00 to 09:00. These restraint tubes were washed \& sterilized between each restraint cycles. Mice in the tubes were not having any contact with food \& water throughout this time period. Likewise food- and water-deprived, but not restrained, mice were used as control animals (Jin et al., 2013).

\subsection{Expression analysis of GLO-1 using real-time RT-PCR}

The real time RT-PCR studies were performed according to the procedure described by Siddiqui et al. (2019). The primer sequence used in this study was; GLO-1 (Sense, 5'-CATTCAAGACCCTGACGG-3'; antisense, 5'-CATCAGTCCCCAACGCTTC-3') and GAPDH (sense, 5'-GTATGACTCCACTCACGGCA-3'; antisense, 5'-TCCACGACATACTCAGCACC-3').

\subsection{Immunohistochemical expression studies of GLO-1 protein}

In the first step the slides were deparaffinized in xylene, then rehydrated in graded isopropyl alcohol (70\%, 90\% and $100 \%$,) then were kept in deionized water for fifteen minutes. Then, slides were placed on the rack, additional water was removed and PBS was added onto the tissue sections for five minutes. Then PBS was removed and slides were covered with blocking solution. Slides were then kept in wet chamber and incubated at $42{ }^{\circ} \mathrm{C}$ for fifteen to twenty minutes. In the meantime, primary and secondary (antibodies) were diluted by blocking solution with ratio of 1:100 and centrifuged at 10,000 RPM for ten minutes to avoid antibodies clumps. After blocking, tissue sections were incubated with primary antibodies at $42{ }^{\circ} \mathrm{C}$ in incubator for forty five minutes. Slides were washed three times with PBS for five mins each. Secondary antibodies were then put on the tissue sections and incubated at forty two $\left(42^{\circ} \mathrm{C}\right)$ in incubator for forty five minutes. After incubation with secondary antibodies, slides were washed thoroughly with PBS 03 times for five mins each. Slides were then reacted with DAB solution for 10 minutes. Nuclei were stained with hematoxylin for three minutes. In the end the slides were mounted with DPX mounting media (Siyal et al., 2020).

\subsection{Statistical analysis}

Data was analyzed by SPSS version 21 software. Numerical variables were represented as means \pm SEM. Comparison between groups were performed using paired t-test followed by one way-ANOVA and $p$-value $<$ or $=$ 0.05 was considered statistically significant.

\section{Results}

\section{1. mRNA expression of GLO-1 genes in whole brain}

Figure 1 demonstrates the mRNA expression of GLO-1 in mice brain of different groups. A significant increase ( 6.20 fold) in mRNA expression can be observed in anxiety group $(\mathrm{p}<0.001)$ as compared to the normal group. Significant decreases in the mRNA expression were found in the animals treated with the test compounds in a dose dependent manner compared to the anxiety model. In the animal group treated with eugenol at the dose of $50 \mathrm{mg} / \mathrm{kg}$, the mRNA expression was 4.50 fold change as compared to the anxiety group $(\mathrm{p}<0.001)$, whereas 2.57 fold change was observed in animals treated with eugenol at the dose of $100 \mathrm{mg} / \mathrm{Kg}$ in comparison with anxiety group $(\mathrm{p}<0.001) .3 .90$ fold change was seen in animals treated with Eu-Lipo at the dose of $15 \mathrm{mg} / \mathrm{Kg}$ and expression level was decreased to 1.90 fold in the animals treated with Eu-Lipo at the dose of $30 \mathrm{mg} / \mathrm{kg}$ as compared to the anxiety group $(\mathrm{p}<0.001)$. The diazepam was given to animals for reference purpose. The result showed the better activity of Eu-Lipo at the low doses as compared to the compound alone.

\subsection{Immunohistochemical expression of GLO-1 protein in whole brain}

Figure 2 demonstrates the immunohistochemical expression of GLO-1 protein in the whole brain of animals treated with different conditions. Figure 2A shows the normal pattern of expression of GLO-1 protein, while the expression level was increased in anxiety group (Figure 2B). There is a decrease in expression of GLO- 1 protein as seen in animals treated with eugenol at the dose of $50 \mathrm{mg} / \mathrm{Kg}$ and $100 \mathrm{mg} / \mathrm{Kg}$ (Figure 2C and 2D respectively) as compared to the anxiety group. We also observed the decreased GLO-1 protein expression in the animals treated with EuLipo at a relatively lower dose i.e. $15 \mathrm{mg} / \mathrm{Kg}$ and $30 \mathrm{mg} /$ $\mathrm{Kg}$ as compared to the anxiety group (Figure $2 \mathrm{E}$ and $2 \mathrm{~F}$ respectively). The expression level was also decreased in

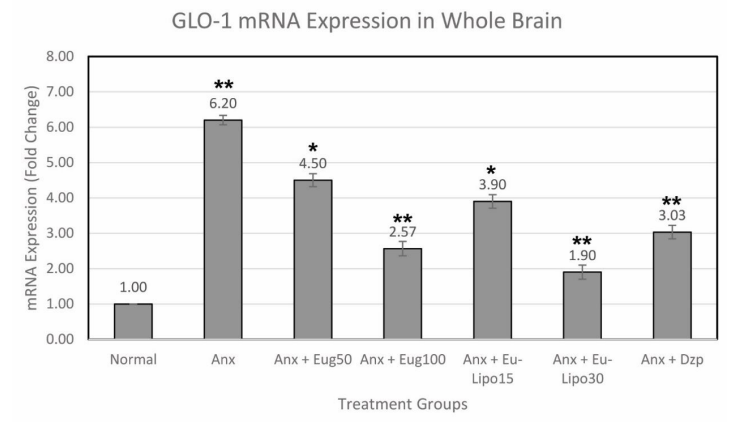

Figure 1. mRNA expressions of GLO-1 gene in whole brain by real time RT-PCR in different treatment groups. $\left({ }^{*}=p<0.05,{ }^{* *}=p<0.005\right)$. 

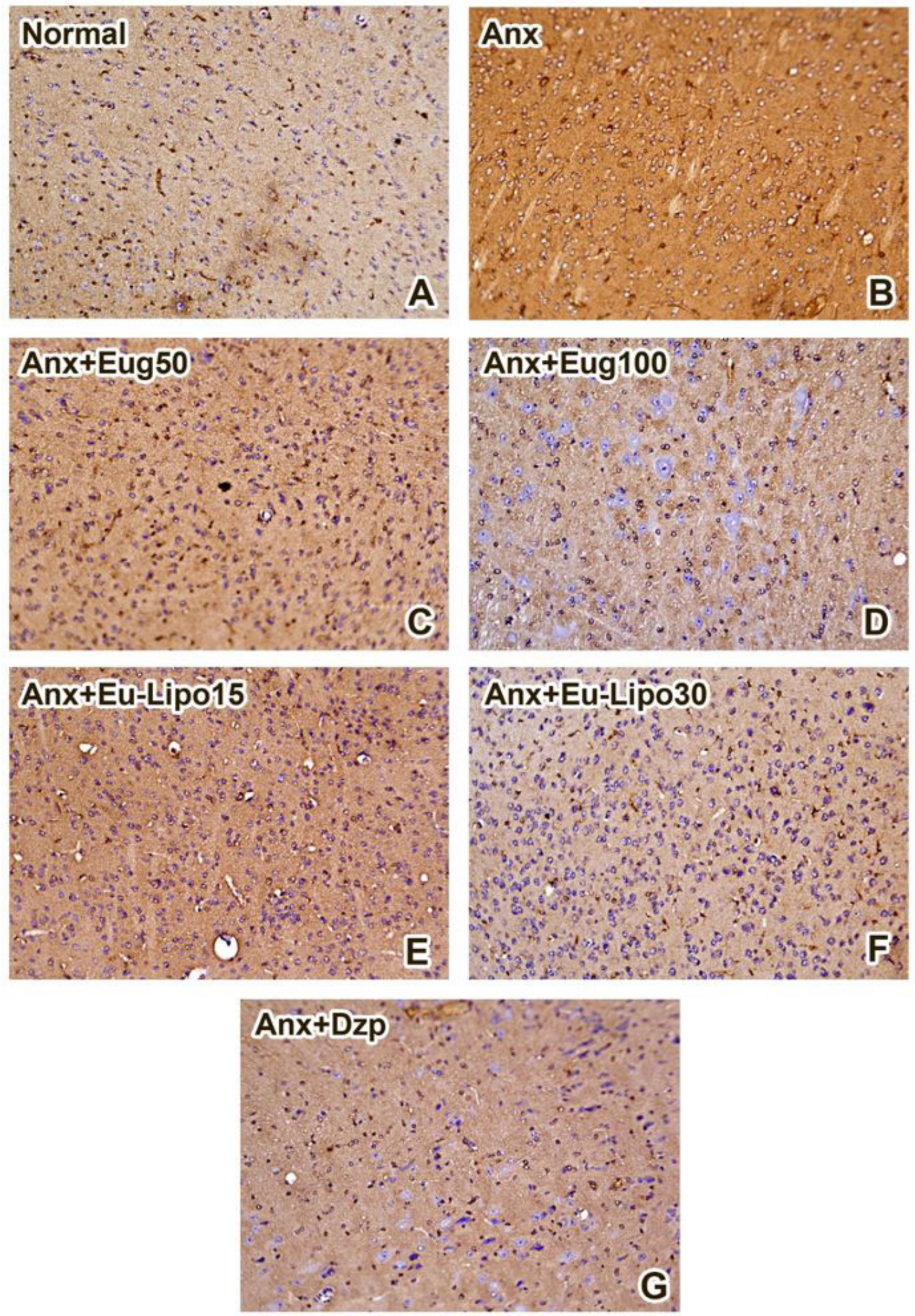

Figure 2. Immunohistochemical expression of GLO-1 protein in whole brain in different treatment groups. 
GLO-1 Protein Expression in Whole Brain

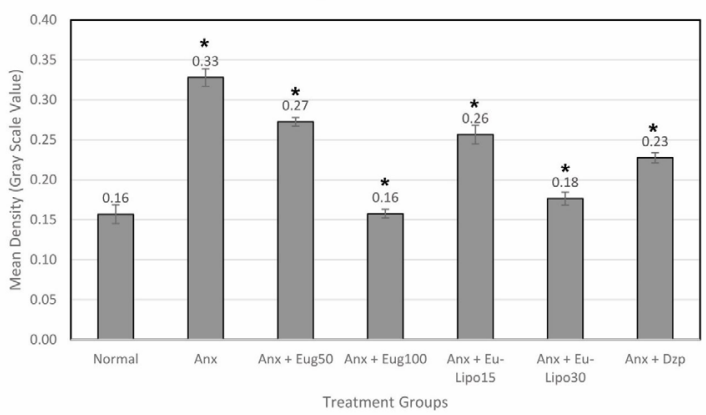

Figure 3. Quantification of GLO-1 immunohistochemical images in gray scale value in different treatment groups ( ${ }^{*} \mathrm{p}<0.001$ ).

the animals treated with diazepam at the dose of $1 \mathrm{mg} /$ $\mathrm{Kg}$ (Figure $2 \mathrm{G}$ ). This group was used as a positive control. The results of IHC images were analyzed by calculating the mean density (gray scale value) of images by Nikon Elements-D software as shown in Figure 3 Through this method, the IHC results were quantified and validated.

\section{Discussion}

Anxiety and depression are most found chronic psychiatric disorders. According to WHO depression will become second leading cause of disability and deaths till 2020 (WHO, 2001). Medicinal herbs have been practiced worldwide. Regarding health care developing countries rely on them (Amos et al., 2001). Many herbal plants contain eugenol possessing many activities (Muller et al., 2006). In comparison to our study we also found that eugenol possess anti-anxiety effects as assessed by the behavioral tests. In traditional practices, it is also effective in reversing the short and long term memory (Halder et al., 2011). There are no conclusive evidence regarding mechanism of action of eugenol although it has been reported that they inhibit calcium and sodium currents in dental afferent neurons, suggestive of its mechanism for analgesic effect (Chung et al., 2008). It is also suggested that they may be involved in neuronal excitability and regulation of cellular activity (Sahadevan and Rema, 2002). But whether this mechanism works for CNS is still obscure, we found that over expression of GLO-1 occurs during anxiety and once treated with eugenol and its lypossom-based nanoparticles at different doses, the anxiety was reduced. Glyoxalase system contains enzyme named glyoxalase 1 (GLO-1), it is a metabolic pathway which detoxifies alpha-oxo-aldehydes, in particularly methylglyoxal (MG). MG is primarily made by the breakdown of the glycolytic (intermediates), glyceraldehyde 3 phosphates and dihydroxyacetone phosphate. GLO-1 expression is also related with anxiety behavior. A causal role of GLO-1 in anxiety behavior by using viral vectors for over expression in the anterior cingulate cortex was found and it was observed that local GLO-1 over expression increased anxiety behavior (Distler and Palmer, 2012). In comparison to our study we also found out by IHC that there is an over expression of GLO-1 during anxiety.
Striatum and motor cortex which are part of motor system have glucocorticoid receptor density that renders them, to the risk of stress (Metz et al., 2005). In our study we found out that both GLO-1 is over expressed in anxiety. In a study, eugenol's various pharmacological effects were evaluated at $100 \mathrm{mg} / \mathrm{kg}$ dose in animal models. To check the anti-nociceptive effects three models were used Viz Tail flick test, acetic acid induced writhing tests and hot plate tests. Eugenol and Eu-Lipo showed significant effect in all of the three models and this effects was in accordance with previous studies (Müller et al., 2006). In comparison to our study we used two animal models of anxiety which were elevated maze plus and open field and observed that eugenol reduced anxiety. In amygdala, the GABAergic transmission controls the emotions (Tasan et al., 2011), like anxiety and fear (Tovote et al., 2015) also inducing pathological anxiety traits (Shen et al., 2010). Its tonic inhibitions also play critical function in severe neurological diseases and neuronal excitability modulation (Brickley and Mody, 2012). The current study revealed that when the animals were treated with the test compounds i.e. eugenol and its liposome-based nanocarrier, the expression of GLO-1 gene and protein were decreased, thus proving their anxiolytic activities.

\section{Conclusion}

It is concluded that eugenol and liposome-based nanocarrier loaded with eugenol (Eu-Lipo) protect anxiety disorder in mice in a dose dependent manner. Moreover, the results were better observed in animals treated with nanocarriers compared to the eugenol alone. The underlying molecular mechanism by which the test compounds exert their activity was down-regulation of GLO-1 gene and protein in mice brain. This may be one mechanism by which the test compounds showed their anxiolytic activity. Therefore, the study suggests to explore more molecular mechanisms of the test compounds to make it better drug candidate for future therapeutics.

\section{Acknowledgements}

The authors thank to Ziauddin University for providing the research laboratories facility to carry out the presented research work.

\section{References}

AMOS, S., KOLAWOLE, E., AKAH, P., WAMBEBE, C. and GAMANIEL, K., 2001. Behavioral effects of the aqueous extract of Guiera senegalensis in mice and rats. Phytomed, vol. 8, no. 5, pp. 356-361. http://dx.doi.org/10.1078/0944-7113-00056. PMid:11695878.

ANDREWS, G., SANDERSON, K., SLADE, T. and ISSAKIDIS, C., 2000. Why does the burden of disease persist? Relating the burden of anxiety and depression to effectiveness of treatment. Bulletin of the World Health Organization, vol. 78, no. 4, pp. 446-454. PMid:10885163.

BALDESSARINI, R.J., 2006. Drug therapy of depression and anxiety disorders. In: L.L. BRUNTON, R. HILAL-DANDAN and B.C. 
KNOLLMANN, eds. Goodman and Gilman's: the pharmacological basis of therapeutics. New York: McGraw-Hill, pp. 429-460.

BARKOW, K., HEUN, R., WITTCHEN, H.U., ÜSTÜN, T.B., GÄNSICKE, M. and MAIER, W., 2004. Mixed anxiety-depression in a 1 year follow-up study: shift to other diagnoses or remission? Journal of Affective Disorders, vol. 79, no. 1-3, pp. 235-239. http:// dx.doi.org/10.1016/S0165-0327(02)00343-9. PMid:15023500.

BRADY, K.T. and SINHA, R., 2005. Co-occurring mental and substance use disorders: the neurobiological effects of chronic stress. The American Journal of Psychology, vol. 162, no. 8, pp. 1483-1493. http://dx.doi.org/10.1176/appi.ajp.162.8.1483. PMid:16055769.

BRICKLEY, S.G. and MODY, I., 2012. Extrasynaptic GABAA receptors: their function in the CNS and implications for disease. Neuron, vol. 73, no. 1, pp. 23-34. http://dx.doi.org/10.1016/j. neuron.2011.12.012. PMid:22243744.

CHUNG, G., RHEE, J.N., JUNG, S.J., KIM, J.S. and OH, S.B., 2008. Modulation of CaV2. 3 calcium channel currents by eugenol. Journal of Dental Research, vol. 87, no. 2, pp. 137-141. http:// dx.doi.org/10.1177/154405910808700201. PMid:18218839.

COULEHAN, J.L., SCHULBERG, H.C., BLOCK, M.R., MADONIA, M.J. and RODRIGUEZ, E., 1997. Treating depressed primary care patients improves their physical, mental, and social functioning. Archives of Internal Medicine, vol. 157, no. 10, pp. 1113-1120. http://dx.doi. org/10.1001/archinte.1997.00440310079008. PMid:9164377.

DISTLER, M.G. and PALMER, A.A., 2012. Role of Glyoxalase 1 (Glo1) and methylglyoxal (MG) in behavior: recent advances and mechanistic insights. Frontiers in Genetics, vol. 3, pp. 250. http://dx.doi.org/10.3389/fgene.2012.00250. PMid:23181072.

HALDER, S., MEHTA, A.K., KAR, R., MUSTAFA, M., MEDIRATTA, P.K. and SHARMA, K.K., 2011. Clove oil reverses learning and memory deficits in scopolamine-treated mice. Planta Medica, vol. 77, no. 8, pp. 830-834. http://dx.doi.org/10.1055/s-0030-1250605. PMid:21157682.

IRIE, M., MIYATA, M. and KASAI, H., 2005. Depression and possible cancer risk due to oxidative DNA damage. Journal of Psychiatric Research, vol. 39, no. 6, pp. 553-560. http://dx.doi.org/10.1016/j. jpsychires.2005.01.009. PMid:16005897.

JIN, J., WANG, X., WANG, Q., GUO, X., CAO, J., ZHANG, X., ZHU, T., ZHANG, D., WANG, W., WANG, J., SHEN, B., GAO, X., SHI, Y. and ZHANG, J., 2013. Chronic psychological stress induces the accumulation of myeloid-derived suppressor cells in mice. PLoS One, vol. 8, no. 9, pp. e74497. http://dx.doi.org/10.1371/ journal.pone.0074497. PMid:24058577.

LEPICARD, E.M., VENAULT, P., PEREZ-DIAZ, F., JOUBERT, C., BERTHOZ, A. and CHAPOUTHIER, G., 2000. Balance control and posture differences in the anxious BALB/CByJ mice compared to the non anxious C57BL/6J mice. Behavioural Brain Research, vol. 117, no. 1-2, pp. 185-195. http://dx.doi.org/10.1016/S01664328(00)00304-1. PMid:11099772.

MCEWEN, B.S., 2000. The neurobiology of stress: from serendipity to clinical relevance. Brain Research, vol. 886, no. 1-2, pp. 172-189. http://dx.doi.org/10.1016/S0006-8993(00)02950-4. PMid:11119695.

METZ, G.A., JADAVJI, N.M. and SMITH, L.K., 2005. Modulation of motor function by stress: a novel concept of the effects of stress and corticosterone on behavior. The European Journal of Neuroscience, vol. 22, no. 5, pp. 1190-1200. http://dx.doi. org/10.1111/j.1460-9568.2005.04285.x. PMid:16176362.

MÜLLER, M., PAPE, H.C., SPECKMANN, E.J. and GORJI, A., 2006. Effect of eugenol on spreading depression and epileptiform discharges in rat neocortical and hippocampal tissues. Neuroscience, vol. 140, no. 2, pp. 743-751. http://dx.doi.org/10.1016/j. neuroscience.2006.02.036. PMid:16563641.
PRAKASH, P. and GUPTA, N., 2005. Therapeutic uses of Ocimum sanctum Linn (Tulsi) with a note on eugenol and its pharmacological actions: a short review. Indian Journal of Physiology and Pharmacology, vol. 49, no. 2, pp. 125-131. PMid:16170979.

SAHADEVAN, P. and REMA, M.N., 2002. A comparative experimental study of the anticonvulsant effect of three calcium channel blockers in albino mice. International Journal of Pharmacology, vol. 34, no. 1, pp. 52-55.

SELVAN, P., MALATHI, R.R. and RAJAN, R.R., 2016. Effect of 4-Allyl-2methoxyphenol (eugenol) on motor co-ordination in subacute restraint stress Induced wistar albino rats. Journal of Applied Pharmaceutical Science, vol. 6, no. 11, pp. 120-125. http://dx.doi. org/10.7324/JAPS.2016.601119.

SHARMA, M., RAUNIAR, G.P. and DAS, B.P., 2012. Experimental study of various central nervous system effects of eugenol in mice and rats. Health Renaissance, vol. 10, no. 3, pp. 208-214. http://dx.doi.org/10.3126/hren.v10i3.7137.

SHEN, Q., LAL, R., LUELLEN, B.A., EARNHEART, J.C., ANDREWS, A.M. and LUSCHER, B., 2010. $\gamma$-Aminobutyric acid-type A receptor deficits cause hypothalamic-pituitary-adrenal axis hyperactivity and antidepressant drug sensitivity reminiscent of melancholic forms of depression. Biological Psychiatry, vol. 68, no. 6, pp. 512-520. http://dx.doi.org/10.1016/j.biopsych.2010.04.024. PMid:20579975.

SIDDIQUI, R.A., SIMJEE, S.U., KABIR, N., ATEEQ M., SHAH, M.R. and HUSSAIN, S.S., 2019. N-(2-hydroxyphenyl) acetamide and its gold nanoparticle conjugation prevent glycerol-induced acute kidney injury by attenuating inflammation and oxidative injury in mice. Molecular and Cellular Biochemistry, vol. 450, no. 1-2, pp. 43-52. http://dx.doi.org/10.1007/s11010-018-3371-3. PMid:29790115.

SINGH, S.K., BARRETO, G.E., ALIEV, G. and ECHEVERRIA, V., 2017. Ginkgo biloba as an alternative medicine in the treatment of anxiety in dementia and other psychiatric disorders. Current Drug Metabolism, vol. 18, no. 2, pp. 112-119. http://dx.doi.or g/10.2174/1389200217666161201112206. PMid:27908257.

SIYAL, F.J., MEMON, Z., SIDDIQUI, R.A., ASLAM, Z., NISAR, U., IMAD, R. and SHAH, M.R., 2020. Eugenol and liposome-based nanocarriers loaded with eugenol protect against anxiolytic disorder via down regulation of neurokinin-1 receptors in mice. Pakistan Journal of Pharmaceutical Sciences, vol. 33, no. 5, pp. 2275-2284. PMid:33832901.

TASAN, R.O., BUKOVAC, A., PETERSCHMITT, Y.N., SARTORI, S.B., LANDGRAF, R., SINGEWALD, N. and SPERK, G., 2011. Altered GABA transmission in a mouse model of increased trait anxiety. Neuroscience, vol. 183, pp. 71-80. http://dx.doi.org/10.1016/j. neuroscience.2011.03.051. PMid:21458543.

TOVOTE, P., FADOK, J.P. and LÜTHI, A., 2015. Neuronal circuits for fear and anxiety. Nature Reviews. Neuroscience, vol. 16, no. 6, pp. 317-331. http://dx.doi.org/10.1038/nrn3945. PMid:25991441.

TREIT, D. and FUNDYTUS, M., 1988. Thigmotaxis as a test for anxiolytic activity in rats. Pharmacology, Biochemistry, and Behavior, vol. 31, no. 4, pp. 959-962. http://dx.doi. org/10.1016/0091-3057(88)90413-3. PMid:3252289.

WORLD HEALTH ORGANIZATION - WHO, 2001 [viewed 27 March 2012]. Mental health: new understanding: new hope [online]. Geneva: WHO. Available from: http://www.who.int/whr/2001/ en/whr01_en.pdf

ZHANG, Z.J., 2004. Therapeutic effects of herbal extracts and constituents in animal models of psychiatric disorders. Life Sciences, vol. 75, no. 14, pp. 1659-1699. http://dx.doi. org/10.1016/j.lfs.2004.04.014. PMid:15268969. 